\title{
Dysplazje ektodermalne - mechanizmy molekularne odpowiedzialne za występowanie najczęstszych zespołów chorobowych
}

\author{
mgr Alicja Monika Grabar- \\ $\operatorname{czyk}^{\square}$,
}

\section{dr Katarzyna Wertheim-Tysa- rowska,}

\author{
prof. dr hab. Jerzy Bal
}

Zakład Genetyki Medycznej, Instytut Matki i Dziecka, Warszawa

https://doi.org/10.18388/pb.2021_392

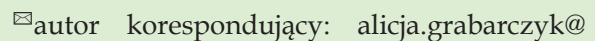
imid.med.pl

Słowa kluczowe: Dysplazje ektodermalne, morfogeneza, szlaki sygnałowe, ektodysplazyna, klasyfikacja

Skróty: ADULT - (ang. acro-dermato-ungual-lacrimal-tooth syndrome); AEC - zespół Hay-Wellsa (ang. ankyloblepharon-ectodermal defects-cleft lip/palate); DE - dysplazje ektodermalne; EDA - ektodysplazyna A; EEC - zespół ektrodaktylii i dysplazji ektodermalnej z rozszczepem podniebienia (ang. ectrodactyly, ectodermal dysplasia, and cleft lip/palate syndrome); HED - hipohydrotyczna dysplazja ektodermalna (ang. hipohidrotic ectodermal dysplasia); TNF - czynnik martwicy guza (ang. tumor necrosis factor) XLHED - hipohydrotyczna dysplazja ektodermalna sprzężona $\mathrm{z}$ chromosomem $\mathrm{X}$ (ang. $\mathrm{X}$ -linked hipohidrotic ectodermal dysplasia)

\section{STRESZCZENIE}

D splazje ektodermalne stanowią dużą grupę genetycznie uwarunkowanych chorób, które charakteryzują się spektrum objawów dotyczących struktur pochodzenia ektodermalnego (najczęściej zębów, włosów, paznokci i gruczołów potowych). Zidentyfikowano kilkadziesiąt genów, których mutacje mogą skutkować wystąpieniem określonego fenotypu. Znane jest podłoże molekularne wielu dysplazji ektodermalnych, które, jak się okazuje, często wynika z zaburzonej komunikacji w szlakach sygnałowych kluczowych dla morfogenezy zarodkowej w zakresie powstawania tkanek pochodzenia ektodermalnego lub nieprawidłowo funkcjonujących specyficznych kompleksów białkowych odpowiedzialnych za homeostazę, przyleganie i stabilność komórek w tkankach. Na podstawie powyższych danych zaproponowano odmienne podejścia klasyfikacyjne dla dysplazji ektodermalnych, w których punktem wyjścia były objawy kliniczne lub informacje o podłożu molekularnym. Rozwój technologii molekularnych pozwolił na przestrzeni lat znacznie rozszerzyć możliwości diagnostyczne dla pacjentów $\mathrm{z}$ objawami dysplazji ektodermalnych. $\mathrm{Z}$ pewnością $\mathrm{w}$ najbliższych latach należy się spodziewać identyfikacji nowych genów i mutacji związanych $\mathrm{z}$ patogenezą dysplazji ektodermalnych.

\section{WPROWADZENIE}

Dysplazje ektodermalne (DE) to szeroka grupa dziedzicznych zespołów chorobowych, w których dochodzi do zaburzeń rozwoju tkanek pochodzenia ektodermalnego. Ektoderma jest listkiem zarodkowym powstającym na wczesnych etapach rozwoju embrionalnego. Daje początek neuroektodermie, z której rozwija się układ nerwowy oraz ektodermie powierzchniowej, która różnicuje się w tkanki nabłonka, przydatki skórne i szkliwo zębów [1]. Zaburzenia formowania się ektodermy, jej podziałów, różnicowania oraz skomplikowanych interakcji z sąsiadującą mezodermą mogą spowodować szeroką gamę objawów dotyczących skóry, włosów, paznokci, zębów, gruczołów potowych i łojowych, tkanek oka, ucha, układu nerwowego i gruczołów wydzielniczych [2,3]. Od typu choroby i rodzaju zaburzenia leżącego u jej podstaw zależy, które tkanki ulegają zniekształceniu [4]. Zgodnie $\mathrm{z}$ aktualną definicją, dysplazje ektodermalne to uwarunkowane genetycznie choroby wpływające na rozwój i/lub homeostazę dwóch lub więcej pochodnych ektodermalnych, w tym włosów, zębów, paznokci i niektórych gruczołów [5].

Dziedziczenie dysplazji ektodermalnych może odbywać się w sposób autosomalny recesywny, autosomalny dominujący oraz sprzężony z chromosomem $\mathrm{X}$. Opisano ponad 180 dysplazji ektodermalnych. Dla wielu z nich określono podłoże molekularne i wskazano geny, których wadliwe produkty białkowe leżą u podstaw rozwoju danej choroby [2,6]. Należy jednak zaznaczyć, że niejednokrotnie defekt jednego genu, zależnie od typu mutacji, może być łączony z kilkoma jednostkami chorobowymi. $Z$ tego powodu liczba genów, których mutacje odpowiedzialne są za fenotypy dysplazji nie równa się liczbie rozpoznanych zespołów.

Dysplazje ektodermalne są chorobami rzadkimi. Najczęstszym zespołem $\mathrm{w}$ tej grupie jest hipohydrotyczna dysplazja ektodermalna sprzężona $\mathrm{z}$ chromosomem X (XLHED, OMIM 305100), której częstość występowania w populacji szacuje się na 1:50 000-1:100 000 osób [7].

W niniejszej pracy przedstawiono aktualną wiedzę odnośnie dysplazji ektodermalnych wraz ze wskazaniem głównych mechanizmów molekularnych wpływających na fenotyp $\mathrm{w}$ najczęstszych formach zaburzeń rozwojowych związanych z ektodermą jak też problemy związane z ich klasyfikacją.

Na problematykę złożoności klasyfikacji dysplazji ektodermalnych składa się kilka charakterystycznych dla tej grupy chorób aspektów dotyczących zarówno 
objawów klinicznych jak i niepełnej wiedzy o patologii molekularnej. Zaliczamy do nich:

1) dużą liczbę chorób, które określane są mianem dysplazji ektodermalnej;

2) zróżnicowanie w ekspresji i nasileniu objawów, nawet w obrębie tej samej jednostki chorobowej;

3) nakładanie się cech fenotypowych między różnymi typami DE; $\mathrm{DE}$;

4) Skrajnie niską częstość populacyjną niektórych typów

6) zróżnicowanie podłoża genetycznego;

7) niepełną penetrację wariantów niektórych genów;

8) pseudodominujący charakter dziedziczenia niektórych zespołów [8]. Stanowi to dodatkowo znaczący problem dla przeprowadzenia właściwego procesu diagnostycznego. Celem podejmowanych od szeregu lat prób klasyfikacji DE jest przyjęcie optymalnego algorytmu badawczego.

\section{SZLAKI SYGNAŁOWE W ROZWOJU ZARODKOWYM}

\section{ORGANOGENEZA EKTODERMALNA}

Rozwój skóry i jej przydatków jest ściśle regulowany na wczesnych etapach rozwoju zarodkowego w procesach różnicowania się komórek macierzystych pochodzących z ektodermy i mezodermy [9]. W wyniku molekularnej komunikacji między listkami zarodkowymi, z ektodermy powstaje naskórek wraz z przydatkami, natomiast $\mathrm{z}$ mezodermy wykształca się zarodkowa mezenchyma [2]. Morfogeneza opiera się zatem na specyficznej komunikacji epitelialno-mezenchymalnej możliwej dzięki cząsteczkom sygnałowym zorganizowanym w szlaki, które regulują m.in. podziały, różnicowanie i śmierć komórek [10]. Zakłócenie interakcji może skutkować nieprawidłowym kształtowaniem wytworów skórnych. Obecnie znanych jest kilka szlaków sygnałowych, których zaburzenia mają wpływ na rozwój dysplazji ektodermalnych (m.in. Wnt, hedgehog, TNF, NFкB, EDA, gap-junction - connexin, axin) oraz czynników transkrypcyjnych (np. TP63) regulujących ekspresję wczesnych genów związanych z organogenezą [2].

Elementem wspólnym i charakterystycznym dla rozwoju organów ektodermalnych jest tworzenie się zgrubień naskórkowych (plakod), które są swoistym zarodkowym centrum sygnałowym. Wydzielają wiele cząstek sygnałowych należących do kilku kluczowych rodzin białkowych, np. czynników wzrostu fibroblastów (FGF), BMP, Wnt, TGF- $\beta$, Hedgehog, TNF. Wzrost epitelium i mezenchymy powiązany z komunikacją między tymi warstwami prowadzi do wykształcenia konkretnych przydatków skórnych, zależnie od sygnałów molekularnych i zaangażowanych szlaków sygnałowych [10].

\section{SZLAK SYGNAŁOWY EKTODYSPLAZYNY A}

Najważniejszym embrionalnym szlakiem sygnałowym z punktu widzenia rozpoznania klinicznego najczęstszych dysplazji ektodermalnych jest należący do rodziny ścieżek związanych z czynnikiem martwicy guza (ang. tumor necrosis factor, TNF) szlak ektodysplazyny A. Sygnały molekularne przekazywane przez ten szlak wpływają na rozwój organów pochodzenia ektodermalnego. Mutacje w genach kodujących białka zaangażowane w poszczególne elementy szlaku skutkują całkowitym brakiem lub powstaniem nieprawidłowo wykształconych struktur ektodermalnych takich jak włosy, zęby i gruczoły potowe. Przykładowo, za wystąpienie hipohydrotycznej dysplazji ektodermalnej sprzężonej z chromosomem X (ang. X-linked hipohidrotic ectodermal dysplasia, XLHED) odpowiadają mutacje w genie EDA, którego produkt, ektodysplazyna A - EDA, jest niezbędna do zapoczątkowania kaskady sygnałowej [1]. Uważa się, że mutacje zaledwie czterech genów (EDA, EDAR, EDARADD i WNT10A) są związane z ponad 90\% przypadków hipo/anhydrotycznych dysplazji ektodermalnych [11]. Trzy z powyższych genów są kluczowymi komponentami szlaku EDA.

Ektodysplazyna A - EDA jest białkiem należącym do rodziny TNF-a zaangażowanym bezpośrednio w interakcję epitelialno-mezenchymalną $\mathrm{w}$ rozwoju zarodkowym kręgowców [12-13]. Wyróżniono 8 izoform białka EDA, jednak tylko dwie z nich wydają się odgrywać istotną rolę funkcjonalną: EDA-A1 (391aa) i EDA-A2 (389aa) [14].

Obie izoformy EDA są białkami trimerycznymi zakotwiczonymi w błonie komórkowej krótkim fragmentem N-konca, podczas gdy C-końcowe fragmenty tworzą zewnątrzkomórkowe domeny: miejsce cięcia furyną, domenę kolageno-podobną oraz domenę homologiczną do TNF $[10,13]$. Ludzka domena TNF jest homologiczna w 100\% z mysią, natomiast pozostała część białka EDA wykazuje około 95\% homologii [14]. Dzięki temu podobieństwu możliwe było przeprowadzenie badań funkcjonalnych mających na celu stworzenie mysich mutantów o fenotypie XLHED [15-19].

Zależności funkcjonalne zaobserwowane $\mathrm{u}$ myszy mają proste przełożenie na dostępną dziś wiedzę na temat szlaku sygnałowego ektodysplazyny A. Trimeryczny ligand EDA-A1 łączy się z trimerycznym receptorem błonowym EDAR, dzięki czemu angażowany zostaje wewnątrzkomórkowy adaptor EDARADD i specyficzne cząsteczki sygnałowe (jest to tzw. droga klasyczna, kanoniczna) [20]. Izoforma EDA-A2, której domena TNF jest skrócona o 2 aminokwasy, nie ma zdolności łączenia się z EDAR. Wykazano, że istnieje dla niej specyficzny receptor EDA2R (inna nazwa XEDAR), który nie wiąże adaptora i przekazuje informację wprost na wewnątrzkomórkowe cząsteczki sygnałowe (droga alternatywna, niekanoniczna) $[21,22]$.

Kanoniczna izoforma EDAR posiada 448 aminokwasów $\mathrm{i}$ jest białkiem transbłonowym I stopnia, składającym się z domeny zewnątrzkomórkowej (159 aminokwasów), domeny hydrofobowej (52 aminokwasy) i domeny wewnątrzkomórkowej (237 aminokwasów) zawierającej domenę śmierci, poprzez którą łączy EDARADD. Mutacje w genie EDAR w regionie kodującym miejsce przyłączania liganda EDA-A1 skutkują recesywną formą HED, natomiast mutacje w domenie wewnątrzkomórkowej korelowane są z HED dziedziczoną autosomalnie dominująco [10,23].

Izoformy receptora EDA2R (XEDAR) (297 i 318 aminokwasów) są zaangażowane w rzadziej wykorzystywany szlak sygnałowy za pośrednictwem liganda EDA-A2. Teoretycznie uznaje się, że mutacje typu utraty funkcji EDA2R 


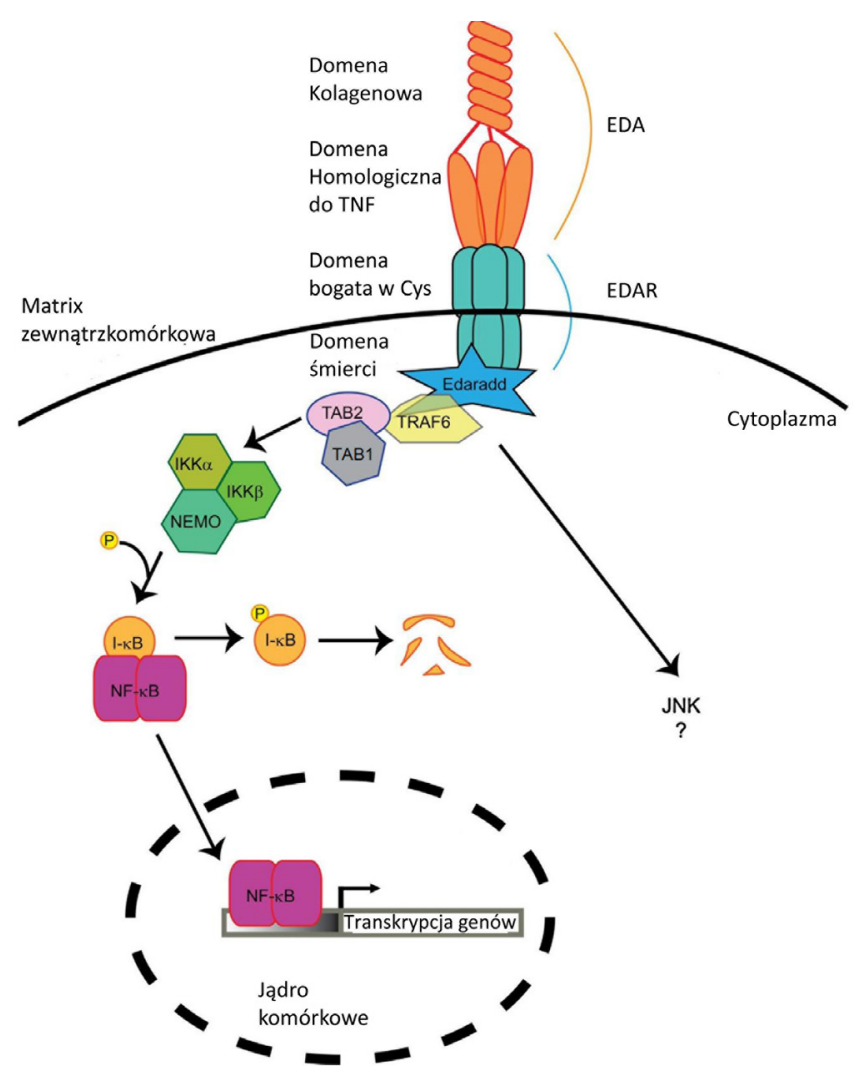

Rycina 1. Transdukcja sygnału przez szlak ektodysplazyny i NEMO- droga kanoniczna [27]. Przeniesienie sygnału z receptora EDAR na białka TRAF nie jest możliwe w bezpośredni sposób i wymaga obecności cząsteczki adaptorowej EDARADD. Jest to białko składające się z 215 aminokwasów (UniProt, modyfikacja danych 4.11.2008) posiadające na C-końcu tzw. domenę śmierci, poprzez którą łączy się z EDAR oraz N-końcową domenę wiążącą czynniki wewnątrzkomórkowe czynniki szlaku aktywacji NF-kB. EDARADD tworzy kompleks z TRAF6, TAB1, TAB2, który z kolei aktywuje kompleks TAK1 [34]. IKK (TAK1) jest kompleksem kinaz IKKa i IKK $\beta$ oraz niekatalitycznej podjednostki NEMO (IKK $\gamma)$, modulatora NF-KB. Aktywacja kompleksu TAK1 prowadzi do aktywacji, fosforylacji i degradacji cytoplazmatycznych białek kompleksu IкB, które są bezpośrednimi inhibitorami czynnika NF-kB. Uwolniony NF-kB trafia do jądra komórkowego, gdzie bierze udział w aktywacji transkrypcji określonych genów docelowych [27-29]. Ogólny schemat działania niekanonicznej drogi aktywacji transkrypcji genów poprzez ligand EDA-2A opiera się na bezpośrednim pobudzeniu czynnika TRAF6 przez aktywowany receptor EDA2R. W efekcie możliwe jest uruchomienie ścieżki sygnałowej wiodącej przez kompleks IKK do aktywacji NF-kB lub indukcja alternatywnej drogi JNK. Z punktu widzenia klinicznego dysplazji ektodermalnych, aktywacja EDA2R jest mało istotna [10].

powinny być powiązane z formami dysplazji ektodermalnych, jednak analizy funkcjonalne na myszach nie potwierdzają udziału tego receptora w patogenezie DE [21,22,24].

Kaskada przekazywania sygnału drogą kanoniczną, od uwolnionego liganda EDA-A1 przez receptor EDAR i adaptor EDARADD, wykazuje podobieństwo do innych szlaków ścieżki związanej z TNF, dlatego zasugerowano powiązanie szlaku ektodysplazyny z aktywacją NF-кB [25]. Rzeczywiście, wykazano, że ekspresja receptora EDAR w komórkach ssaczych indukuje odpowiedź NF-kB. Sygnalizacja EDA-EDAR-EDARADD stymuluje czynniki transkrypcyjne poprzez kanoniczne składowe ścieżki aktywacyjnej NF-kB: TAB2, TAK1, TRAF6 i IKK (Ryc. 1). Zmutowane białka tej ścieżki całkowicie blokują aktywację NFкB indukowaną przez EDARADD [25,26]. Dostępne dane literaturowe wskazują jasno, że głównym mechanizmem transdukcji sygnału przekazywanego poprzez szlak EDA-A1 jest uruchomienie kanonicznej ścieżki aktywacji czynnika transkrypcyjnego NF-kB [22], aczkolwiek proponowano również zaangażowanie alternatywnych szlaków takich jak JNK (ang. c-Jun N-terminal kinase) i wejście na drogę apoptozy. Do tej pory nie uzyskano jednak jednoznacznych wniosków.

Udział szlaku kanonicznego EDA-EDAR-EDARADD i NF-kB w rozwoju zarodkowym jest obecnie bezdyskusyjny. Co ciekawe, reakcje komórek na ekspresję genów regulowaną przez NF-kB nie wiążą się z procesami zapalnymi, jak ma to miejsce w sytuacji pobudzenia innych niż EDAR receptorów TNF. Prawdopodobnie geny transkrybowane $\mathrm{w}$ obu procesach, zapaleniu i rozwoju, podlegają specyficznej aktywacji w zależności od szerszego kontekstu molekularnego i typu komórek [22]. Wykazano, że mysie mutanty białek szlaku NF-kB, TRAF6 lub NEMO, przejawiają objawy zarówno hipohydrotycznej dysplazji ektodermalnej jak i zaburzeń immunologicznych $[30,31]$. Najnowsze dane sugerują, że aktywacja szlaku sygnałowego EDA-A1 powoduje transkrypcję specyficznych chemokin, których rola prawdopodobnie nie ogranicza się do mediacji w stanach zapalnych, ale także w procesach rozwoju struktur ektodermalnych [32]. Dokładna sieć zależności między tymi procesami wymaga szczegółowego zbadania i uzupełnienia.

Aktualnie znanych jest kilkaset mutacji w kluczowych genach szlaku EDA i aktywacji NF-kB. Efekty fenotypowe mutacji w genach EDA, EDAR, EDARADD odpowiadają objawom dysplazji ektodermalnych hipohydrotycznych. Mutacje IKBKG (NEMO) wpływają na fenotyp kilku zespołów dysplazji sprzężonych z chromosomem X, m.in. Incontinentia pigmenti, anhydrotycznej dysplazji ektodermalnej z niedoborem odporności, anhydrotycznej dysplazji ektodermalnej z osteoporozą i niedoborem odporności. Tabela 4 zawiera aktualne dane dotyczące znanych mutacji w ww. genach związanych z dysplazjami ektodermalnymi.

\section{POWIĄZANIA SZLAKU EDA Z INNYMI SZLAKAMI SYGNAEOWYMI}

W rozwoju przydatków skórnych pochodzenia ektodermalnego bierze udział kilka szlaków sygnałowych. Większość z nich posiada znacznie silniejszy wpływ plejotropowy na fenotyp rozwijającego się organizmu niż szlak ektodysplazyny. Udowodniono, że defekty genetyczne w komponentach szlaków WNT, FGF, BMP i HEGDEHOG korelują ze znacznie poważniejszymi wadami rozwojowymi wielu organów, nie ograniczającymi się do przydatków ektodermalnych. Wydaje się, że mutacje genów kodujących białka szlaku ektodysplazyny wpływają na zmianę kształtu, liczby lub pozycji przydatków w organizmie, jednak nie wykluczają ich częściowego rozwoju.[22,33-35].

Szlak EDA wydaje się mieć konserwowane ewolucyjnie znaczenie dla prawidłowego funkcjonowania całej sieci szlaków sygnałowych wpływających na rozwój organów pochodzenia ektodermalnego. Badania na myszach pozwoliły odkryć ścieżki powiązań z jednej strony regulujących działanie szlaku EDA, a z drugiej będących pod jego wpływem regulacyjnym [22]. Przykładowo, szlak Wnt wpływa na szlak ektodysplazyny A poprzez aktywację 
Tabela 1. Warianty w genach związanych z najczęstszymi DE- według bazy danych HGMD®Professional (stan z dnia 19.02.1021)

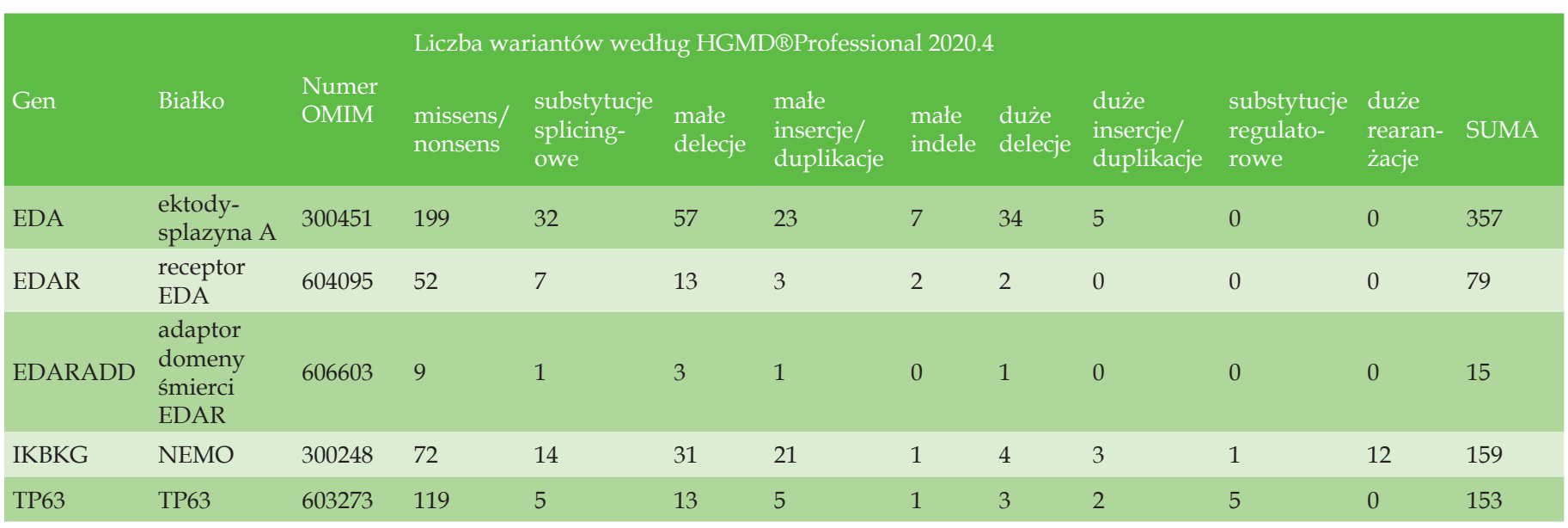

EDA i EDAR, natomiast szlaki aktywiny i BMP stymuluja EDAR [36]. Dyskutowana jest także regulacyjna rola szlaku ektodysplazyny A dla funkcjonowania innych szlaków. Przykładowo, receptor EDAR wpływa na m.in. morfogenetyczne cząsteczki Shh i Fgf20 oraz na antagonistów szlaków Wnt i BMP $[22,37,38]$. Prawidłowe kształtowanie i rozwój wielu struktur ektodermalnych jest zatem w ścisłym powiązaniu z komunikacją i wpływem jednego szlaku na drugi, stąd tak duże trudności w określeniu podłoża molekularnego niektórych typów zaburzeń rozwojowych.

\section{REGULACJA EKSPRESJI GENÓW - P63 (TP63)}

Białko p63 (TP63) funkcjonuje jako czynnik transkrypcyjny w komórkach podstawnych tkanki nabłonkowej naskórka, szyjki macicy, dróg moczowych i prostaty [39]. Posiada kilka regionów funkcjonalnych, z których domeny transaktywacyjna (TA), wiążąca DNA (DBD) oraz odpowiedzialna za oligomeryzację (OD) wykazują homologię z domenami białka p53, w związku z czym białko p63 zaklasyfikowano do rodziny białek supresorowych guza [40]. Co ciekawe, w przeciwieństwie do p53, rola p63 w procesie nowotworzenia jest ograniczona. Wykazano natomiast znaczący wpływ mutacji w genie TP63 na zaburzenia rozwojowe i wystąpienie objawów charakterystycznych dla dysplazji ektodermalnych [41].

Gen TP63 jest skomplikowany pod względem budowy i ekspresji. Posiada dwa promotory, których aktywacja prowadzi do ekspresji dwóch klas białek: zawierających (TA) lub nie zawierających $(\Delta \mathrm{N})$ domeny transaktywacyjnej na N-końcu. W wyniku alternatywnego splicingu obu typów transkryptów, mogą powstać kolejne izoformy białka p63 [39]. Obecnie, według danych z bazy UniProt, opisano 12 izoform p63 [http://www.uniprot.org/uniprot/Q9H3D4]. Pełna funkcjonalność białka p63 zależy od obecności kilku regionów wyspecjalizowanych tj. domeny wiążącej docelowy fragment DNA, domeny SAM odpowiedzialnej za interakcje międzybiałkowe oraz domeny TID hamującej aktywność transaktywacyjną [1]. Początkowo wskazywano na zdolność aktywacji transkrypcji genów docelowych wspólnych dla p53 oraz izoformy TAp63 [39]. Dalsze badania wykazały istnienie unikatowych genów docelowych dla czynnika transkrypcyjnego p63 [42]. Udokumentowano także aktywność regulacyjną izoformy $\Delta N p 63$, pozbawionej domeny TA, w kierunku zarówno aktywacji jak i represji określonych genów [43].

Białko p63 jako czynnik transkrypcyjny reguluje ekspresję wielu genów docelowych, których rola pośrednio lub bezpośrednio związana jest z sygnalizacją epitelialno-mezenchymalną bądź kształtowaniem struktur pochodzenia ektodermalnego. Istnieje co najmniej kilkanaście genów pozostających pod kontrolą p63, których ekspresja w procesach rozwojowych skóry została potwierdzona badaniami funkcjonalnymi lub których udział w organogenezie jest wysoce prawdopodobny. Są to m.in.: BMP7, SUFU, IKKA, GATA3, DLX3, EDAR, CTNNB1, JAG1, JAG2, NOTCH1, NOTCH3, ABBP1, FGFR2B, GJB6, CDH3, IRF6. Ponadto, białka FGF10, BMP7 i BMP2 mogą pozytywnie wpływać na aktywację p63 [5,44,45].

Choroby z grupy dysplazji ektodermalnych związanych przyczynowo z mutacjami w genie TP63 dziedziczą się autosomalnie dominująco (Tab. 1). Mutacje heterozygotyczne powodują co najmniej 6 zespołów chorobowych. Wspólne dla nich defekty rozwojowe dotyczą zębów, włosów i gruczołów sutkowych, choć stopień penetracji i ostateczny fenotyp jest zmienny w zależności od rodzaju mutacji. Ponadto obserwuje się charakterystyczne dla danej jednostki chorobowej objawy dodatkowe takie jak rozszczep wargi/ podniebienia czy nieprawidłowości w budowie kończynszczegóły dalej w tekście [44].

\section{KRÓTKA CHARAKTERYSTYKA WYBRANYCH CHORÓB Z GRUPY DYSPLAZJI EKTODERMALNYCH}

\section{DYSPLAZJE EKTODERMALNE ZWIĄZANE ZE SZLAKIEM SYGNAŁOWYM EDA I NEMO}

Hipohydrotyczne dysplazje ektodermalne

Za wystąpienie większości dysplazji ektodermalnych hipohydrotycznych (ang. hipohidrotic ectodermal dysplasia, HED) odpowiadają mutacje w genach kodujących białka szlaku ektodysplazyny A [11]. Charakterystyczny fenotyp chorych nie pozwala na wytypowanie genu wyłącznie na 
podstawie badań klinicznych, dlatego dla potrzeb poradnictwa genetycznego konieczne jest wykonanie badań molekularnych (analiza genów EDA, EDAR, EDARADD). Najczęstszą postacią tych zaburzeń jest XLHED czyli dysplazja ektodermalna recesywna sprzężona $\mathrm{z}$ chromosomem X (OMIM 305100). Przyczyną schorzenia są mutacje w genie EDA. W związku z typem dziedziczenia XLHED, choroba występuje głównie u mężczyzn, choć objawy o mniejszym stopniu nasilenia obserwuje się także u części kobiet będących heterozygotami pod względem mutacji patogennych w genie EDA [46]. Chorzy posiadają typowe objawy ze strony skóry, włosów, zębów i gruczołów potowych. U noworodków obserwuje się złuszczanie naskórka. U starszych występuje ograniczone i osłabione owłosienie. Dochodzi do niewykształcenia części zawiązków zębów stałych oraz do stożkowatego kształtu tych zębów, które są obecne. Stopień agenezy uzębienia jest zmienny w różnych rodzinach. Najbardziej charakterystyczną cechą wszystkich HED jest zmniejszona lub całkowicie zaburzona zdolność pocenia się związana z brakiem gruczołów potowych, co prowadzi do poważniejszych zmian w organizmie wywołanych hipertermią. Nieklasyczne objawy ze strony innych organów są mniej częste, choć niewykluczone [32,47,48]. Hipohydrotyczne dysplazje ektodermalne dziedziczone w sposób autosomalny dominujący lub recesywny są wynikiem mutacji genów EDAR i EDARADD kodujących odpowiednio receptor oraz adaptor w szlaku sygnałowym ektodysplazyny A. Początkowo uznawano, że mutacje w EDARADD skutkują wyłącznie recesywną postacią dysplazji ektodermalnej (OMIM 614941) [18] jednak, od kilku lat jest jasne, że odpowiadają także za dominującą formą HED (OMIM 614940) [49,50].

Incontinentia pigmenti, czyli zespół nietrzymania barwnika, jest chorobą dziedziczoną w sposób dominujący sprzężony z chromosomem X. Wystąpienie choroby jest spowodowane mutacjami w genie IKBKG (NEMO, IKK $\gamma)$ kodującym ważny element szlaku sygnałowego uaktywniającego czynnik transkrypcyjny NF-kB. W większości przypadków zaburzenia aktywacji NF-kB na poziomie przekazywania sygnału z kompleksu kinaz IKK poprzez NEMO prowadzą do wewnątrzmacicznego obumarcia męskich płodów, w związku z czym incontinentia pigmenti jest chorobą dotyczącą prawie wyłącznie kobiet $[1,29]$. Objawy obejmują charakterystyczne zmiany pigmentacyjne skóry oraz symptomy dotyczące tylko części pacjentów: zaburzenia dentystyczne, dystrofię paznokci, łysienie, zaburzenia okulistyczne i neurologiczne [29,51].

\section{DYSPLAZJE EKTODERMALNE ZWIĄZANE Z CZYNNIKIEM TRANSKRYPCYJNYM P63}

Zespół ektrodaktylii i dysplazji ektodermalnej z rozszczepem podniebienia (ang. ectrodactyly, ectodermal dysplasia, and cleft lip/palate syndrome, EEC) (OMIM 604292) jest stosunkowo często występującym schorzeniem. Mutacje p63 lokalizują się głównie w domenie wiążącej DNA. Nieprawidłowości dotyczą przede wszystkim budowy kończyn (ektro- i syndaktylia; zredukowana liczba palców), włosów, paznokci, zębów, rozszczepów twarzoczaszki oraz budowy układu łzowego i moczowo-płciowego. Nie wszystkie objawy są wyraźnie widoczne u każdego z chorych, odnotowa- no przypadki znacznego międzyosobniczego zróżnicowania klinicznego choroby $[1,52,53]$.

Zespół Hay-Wellsa (ang. ankyloblepharon-ectodermal defects-cleft lip/palate, AEC) (OMIM 106260) powodowany jest mutacjami typu nonsens w domenie SAM p63 odpowiedzialnej za interakcję z innymi białkami szlaków organogenezy. Triada objawów obejmuje aknyloblepharon (zaburzenia budowy skóry między oczami zakłócające otwieranie i ruch gałek ocznych), klasyczne defekty ektodermalne dotyczące włosów i gruczołów potowych oraz rozszczep wargi i/lub podniebienia. Charakterystyczne są zmiany skórne oraz hipo/hiperpigmentacja skóry. Zespół AEC powinien być podejrzewany u noworodków z erytrodermią i rozszczepem twarzoczaszki, zwłaszcza jeśli towarzyszą im nadżerki skóry $[1,54,55]$.

Zespół ADULT (ang. acro-dermato-ungual-lacrimal-tooth syndrome) (OMIM 103285) wynika z mutacji w domenie TID białka p63. Objawami są ektrodaktylia lub syndaktylia, sucha skóra, dysplastyczne paznokcie, zarośnięcie przewodów łzowych oraz hipodoncja. Nie obserwuje się rozszczepów wargi i podniebienia. Niewiele mutacji w genie TP63 odpowiada za wystąpienie tego zespołu [56].

Zespół łokciowo-sutkowy (OMIM 603543) jest powodowany mutacjami w domenie SAM i TID p63. Objawy pokrywają się z cechami innych chorób z tej grupy, stąd trudności w szybkiej diagnozie klinicznej. Charakterystyczne są: ektrodaktylia, hipoplazja sutków i gruczołów sutkowych, rozszczep podniebienia. Nie obserwuje się natomiast objawów ze strony włosów i skóry. Dodatkowe objawy mogą dotyczyć m.in. zaburzeń układu łzowego, moczowo-płciowego, słuchu, ograniczonej potliwości [1,57].

Zespół Rapp-Hodgkin (OMIM 129400) podobnie jak zespół AEC powodowany jest mutacjami w domenie SAM p63. Pod względem objawów właściwie niemożliwe jest rozdzielenie obu zespołów [58]. Najnowsze podejścia klasyfikacyjne (kliniczne, wg. Pagnan i Visnioni) łączy obie jednostki sugerując, że zespoły AEC i Rapp-Hodgkin są dwoma wyznacznikami tej samej choroby [6].

\section{KLASYFIKACJA DYSPLAZJI EKTODERMALNYCH - HISTORYCZNIE}

Jedną z pierwszych prób podziału DE była zaproponowana w 1936 roku strategia pogrupowania znanych zespołów na trzy kategorie. Pierwsza łączyła zaburzenia ze strony gruczołów potowych, włosów i zębów. Druga określała pacjentów o charakterystycznym wyglądzie, z zaburzeniami CUN oraz nieukształtowanymi paznokciami. Trzecia dotyczyła rzadkich zaburzeń funkcjonowania gruczołów wydzielniczych, oczu i zmysłu powonienia [3].

Bardziej precyzyjną jest klasyfikacja zaproponowana przez Freire-Maia $(1971,1977)$ będąca podstawą jednego z aktualnych podziałów opisanych dysplazji ektodermalnych. Za punkt wyjścia w tej klasyfikacji przyjęto objawy kliniczne. Cztery struktury pochodzenia ektodermalnego określono jako "klasyczne” i nadano im kolejne numery: 1 - włosy, 2 - zęby, 3 - paznokcie, 4 - gruczoły po- 
towe, a następnie klasyfikowano poszczególne typy DE na podstawie tego, które z powyższych struktur są zaburzone oraz tego, czy nieprawidłowości występują także $\mathrm{w}$ obrębie innych struktur pochodzenia ektodermalnego $[4,59,60]$.

Kolejny system klasyfikacyjny zaproponowano w 2003 roku. Dysplazje ektodermalne zgrupowano w cztery klasy w zależności od funkcji białek kodowanych przez geny warunkujące daną chorobę:

1) Komunikacja i przekazywanie sygnałów między komórkami,

2) Przyleganie komórek,

3) Regulacja transkrypcji,

4. Procesy rozwojowe.

Była to próba rozszerzenia informacji opartych o obraz kliniczny poprzez zestawienie ich z przyczyną na poziomie molekularnym [61].

Odmienne podejście klasyfikacyjne, które łączyło dane kliniczne i genetyczne, zaproponowali z kolei Priolo i Lagana w 2001 roku, którzy podzielili DE na dwie kluczowe grupy. Pierwsza objęła defekty w regulacji rozwoju i sygnalizacji między ektodermą a mezodermą, dla których określono bądź zasugerowano gen przyczynowy ${ }^{1}$. Druga natomiast zgrupowała choroby, w których określono lub podejrzewano defekt danego białka strukturalnego [62].

Nie wszystkie schematy klasyfikacji dysplazji ektodermalnych zyskały szerokie uznanie i akceptację środowiska naukowego i lekarskiego. Za wiążące i stanowiące bazę dla opracowania aktualnie obowiązującej klasyfikacji przyjmuje się zarówno wymienione wcześniej podejście: kliniczno-molekularne [12] oraz kliniczne [4].

\section{KLASYFIKACJA KLINICZNO-MOLEKULARNA}

Prowadzone na przestrzeni lat szczegółowe analizy genetyczne i molekularne umożliwiły identyfikację genów przyczynowych dla wielu dysplazji ektodermalnych. Zestawiając dane genetyczne $\mathrm{z}$ funkcją białek zaobserwowano, że większość z nich można połączyć w szlaki funkcjonalne kluczowe dla prawidłowego rozwoju zarodkowego [62]. W procesach powstawania przydatków skórnych, ektoderma i mezenchyma komunikują się poprzez szlaki sygnałowe charakterystyczne dla morfogenezy. Wykazano, że do rozwoju DE zasadniczo dochodzi wskutek zaburzeń dwóch różnych mechanizmów, które można też bezpośrednio powiązać z charakterystycznymi objawami klinicznymi (Ryc. 2) [63].

Do grupy 1 zaliczane są te typy DE, w których dochodzi do zaburzenia interakcji między ektodermą a mezenchymą. Geny przyczynowe w tej grupie odpowiadają za regulacje ekspresji białek zaangażowanych w sygnalizację epitelialno-mezenchymalną i wpływają na różnicowanie się komórek oraz procesy apoptotyczne. Wyróżniono dwa podstawowe mechanizmy kontroli:

\footnotetext{
${ }^{1}$ Gen przyczynowy - tu gen, który w wyniku mutacji jest odpowie-
} dzialny za objawy kliniczne DE

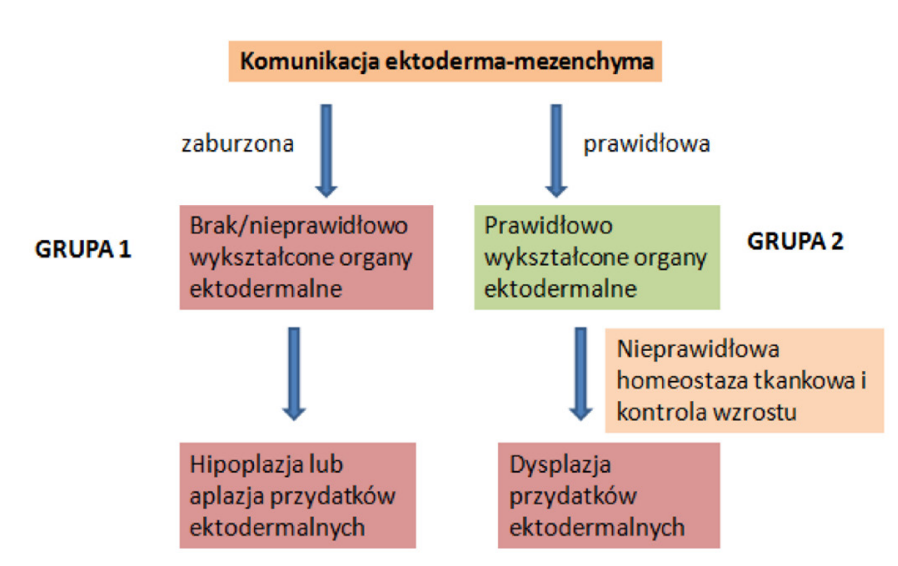

Rycina 2. Klasyfikacji kliniczno-molekularna DE. Możliwe nieprawidłowości obserwowane w rozwoju tkanek pochodzenia ektodermalnego. [wg 1,63]

- Szlak sygnałowy EDA/EDAR/EDARADD oraz regulacyjny NEMO; wpływ na aktywność czynnika jądrowego NF-kB

- Regulacja transkrypcji i/lub ekspresji genów

Cechą charakterystyczną DE grupy 1 jest występowanie klasycznych objawów klinicznych oraz anomalii szkieletowych. Pacjenci wykazują cechy hipoplazji lub aplazji struktur pochodzenia ektodermalnego $[1,63]$.

Grupa 2 łączy te dysplazje ektodermalne, w których zidentyfikowano zaburzoną funkcję białek strukturalnych błony komórkowej (np. nektyny 1, koneksyn, plakofiliny). Ich fizjologiczna rola związana jest z procesami adhezji i komunikacji międzykomórkowej. Zakłócenia tych mechanizmów mogą skutkować zmianami w homeostazie, kontroli wzrostu, odpowiedzi komórkowej i różnicowaniu. Wydaje się, że struktury ektodermalne pierwotnie wykształcają się prawidłowo, ale ulegają modyfikacji w związku z zaburzeniami powyższych mechanizmów. Kliniczne rozpoznanie choroby u pacjentów opiera się na identyfikacji rozszerzonych objawów dermatologicznych takich jak rogowiec dłoni i stóp oraz/lub zaburzeń ze strony wysoce zróżnicowanego nabłonka związanego $\mathrm{z}$ niedosłuchem lub dystrofią siatkówki [63].

W tabeli 2 zebrano dysplazje ektodermalnej z podziałem na grupy zgodnie z założeniami klasyfikacji kliniczno-molekularnej. Zróżnicowanie kliniczne przekłada się na różnorodność genetyczną.

\section{KLASYFIKACJA KLINICZNA}

Opisana powyżej strategia kliniczno-molekularna nie wyczerpuje wiedzy na temat wszystkich DE, skupia się natomiast tylko na tych zespołach, dla których rozpoznano defekt genetyczny i funkcjonalny. Klasyfikacja dysplazji ektodermalnych według objawów klinicznych, nie pomijając kwestii natury genetycznej, uznawana jest za bardziej pragmatyczną i pełniejszą w związku z włączeniem i pogrupowaniem wszystkich znanych syndromów ektodermalnych. Dane do tej klasyfikacji są systematycznie uzupełniane 
Tabela 2. Podział dysplazji ektodermalnych na grupy według klasyfikacji kliniczno-molekularnej.

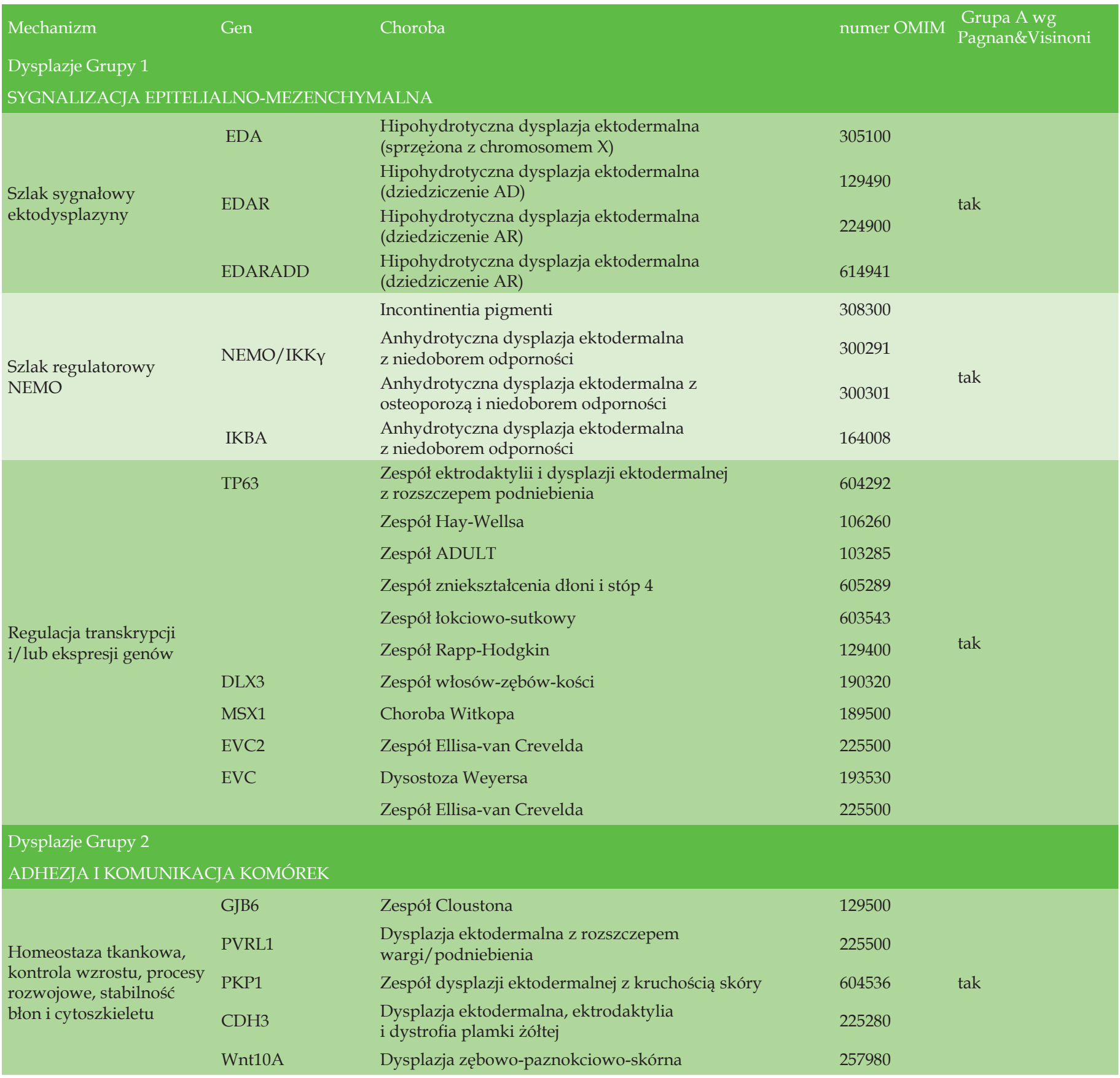

przez grupy specjalistów i dyskutowane na konferencjach naukowych poświęconych temu tematowi. Ostatecznie $\mathrm{w}$ 2009 wprowadzono prosty system klasyfikacji dysplazji ektodermalnych [64].

Strategia podziału DE w zależności od fenotypu opiera się na określeniu „klasycznych” objawów dotyczących struktur pochodzenia ektodermalnego: 1 - włosy, 2 - zęby, 3 - paznokcie, 4 - gruczoły potowe. Zostały one wybrane na podstawie częstości występowania zaburzeń w różnych zespołach dysplazji, odpowiednio 87,1\%, 78,5\%, 73\% i 37,4\%. Kombinacja objawów, obejmująca dwie lub więcej nieprawidłowo uformowanych tkanek spośród powyżej wymienionych, umożliwiła wyodrębnienie 11 podgrup zebranych w Grupę A (Tab. 3). Pozostałe typy DE, w których można określić przynajmniej jedną cechę klasyczną oraz inny objaw ektodermalny, zawarto w ogólnej Grupie B [6,64]. Za inne struktury pochodzenia ektodermalnego uznano gruczoły sutkowe, tarczycę, grasicę, przysadkę mózgową, rdzeń nadnerczy, centralny układ nerwowy, ucho zewnętrzne, melanocyty, rogówkę, spojówkę, gruczoł i przewód łzowy [64].

Grupa A łączy wszystkie najczęstsze i najlepiej poznane dysplazje ektodermalne. W porównaniu do poprzedniego zestawienia, liczba zespołów zmniejszyła się w związku z wykluczeniem, dodaniem lub połączeniem kilku jednostek w jedną. 


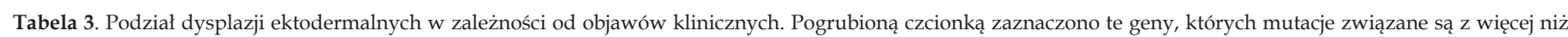
jednym zespołem DE. Dla niektórych zespołów chorobowych nie określono podłoża molekularnego. (wg [6], baza OMIM)

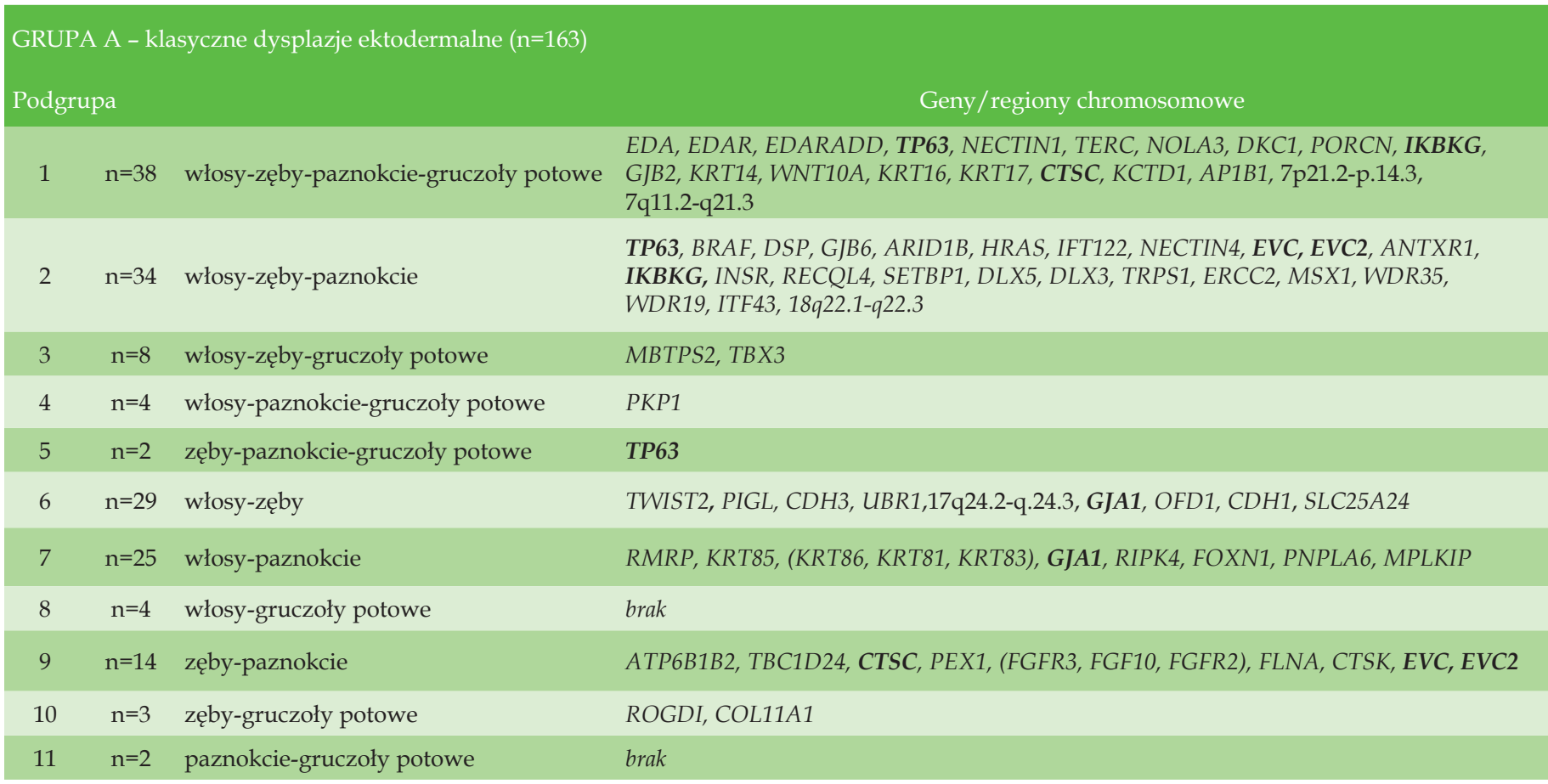

Dla 132 spośród 163 dysplazji ektodermalnych grupy A określono sposób dziedziczenia choroby. 39,9\% z nich to zespoły dziedziczone autosomalnie recesywnie, 33,7\% autosomalnie dominująco, natomiast $7,4 \%$ jest sprzężonych $\mathrm{z}$ chromosomem X. Dla 19\% dysplazji z tej grupy nie określono sposobu dziedziczenia [6].

\section{AKTUALNA KLASYFIKACJA DYSPLAZJI EKTODERMALNYCH}

Najnowsze podejście klasyfikacyjne zostało zaproponowane w 2019 roku jako konsensus skupiający całość dostępnej dotychczas wiedzy na temat molekularnych i klinicznych podstaw dysplazji ektodermalnych. W założeniu, optymalny system powinien łączyć wszystkie dostępne dane genotypowe, fenotypowe, molekularne i strukturalne, których zaburzenie skutkuje wystąpieniem dysplazji i kategoryzować zespoły chorobowe według powyższych informacji. W zależności od potrzeb, za punkt wyjścia przy wyszukiwaniu danych dotyczących konkretnej dysplazji ektodermalnej można przyjąć cechy fenotypowe lub mechanizmy molekularne. Przykładowo, znaczącą liczbę DE można sklasyfikować na podstawie molekularnego powiązania ze szlakami sygnałowymi zaangażowanymi w procesy rozwojowe oraz z kompleksami strukturalnymi (Tabela 4).

Choroby wynikające $z$ obecności wariantów występujących $\mathrm{w}$ genach powiązanych $\mathrm{z}$ dysplazjami ektodermalny$\mathrm{mi}$, ale powodujące defekt tylko jednej struktury ektodermalnej, zostały zaklasyfikowane do grupy izolowanych jednostek chorobowych jak to ma miejsce np. w przypadku objawów związanych z izolowaną hipodoncją powodowaną patogennymi wariantami genu EDA. Należy dodatkowo zaznaczyć, że nie wszystkie patogenne mutacje $\mathrm{w}$ genie przyczynowym DE muszą być prowadzić do wystąpienia objawów klinicznych dysplazji ektodermalnej. Przykładem są mutacje w genie GJB2, które mogą powodować zarówno zaliczany do DE zespół KID (zapalenie rogówki-rybia łuska-głuchota) jak i izolowany niedosłuch czy rogowiec dłoni i stóp [5].

Tabela 4. Klasyfikacja wybranych dysplazji ektodermalnych w zależności od mechanizmów molekularnych [wg: 5].

$\begin{array}{llll}\text { Mechanizm } & \begin{array}{l}\text { Liczba } \\ \text { zespołów DE }\end{array} & \begin{array}{l}\text { Numer OMIM } \\ 305100,129490,224900,308300,\end{array} & \text { Geny } \\ \text { Szlak EDA/NFkB } & 8 & 300291,300301,614940,614941 & \text { EDA, EDAR, EDARADD, IKBKG } \\ \text { Szlak WNT } & 5 & 305600,257980,224750,181270,189500 & \text { PORCN, WNT10A, KCTD1, MSX1 } \\ \text { Szlak TP63 } & 12 & 103285,106260,129400,604292,603543,214350, & \text { TP63, RIPK4, PVRL1, CDH3, PVRL4, DLX3 } \\ & & 225060,225280,613573,601553,263650,190320 & \text { CDH3, KRT85, PKP1, KRT81, KRT86, } \\ \text { Białka strukturalne } & 11 & 225280,602032,604536,158000,225060,129500, & \begin{array}{l}\text { KRT83, NECTIN1, GJB6, GJB2, } \\ \text { KRT14, GJA1, KRT16, KRT17 }\end{array}\end{array}$


Zespoły chorobowe, które objawowo wpisują się w definicję dysplazji ektodermalnych, ale ich etiologia jest nieznana zostały połączone $\mathrm{w}$ grupę łączącą zespoły o podobnym fenotypie. W przypadku identyfikacji molekularnej przyczyny danej choroby, zostanie ona przeniesiona do istniejącej lub nowo powstałej grupy związanej z odpowiednim mechanizmem molekularnym. Powyższy system klasyfikacyjny jest rozbudowany $\mathrm{w}$ takim stopniu, że pozwala uzupełniać dane zgodnie z rozwojem wiedzy na temat podłoża DE.

\section{PODSUMOWANIE}

Dysplazje ektodermalne stanowią dużą grupę rzadkich chorób przebiegających z zaburzeniem struktur ektodermalnych. Na przestrzeni ostatnich kilkudziesięciu lat dokonał się znaczący postęp w zrozumieniu kliniczno-molekularnej patologii choroby, co w sposób znamienny wpłynęło na możliwości diagnostyczne DE oraz umożliwiło poszerzenie wiedzy dotyczącej komunikacji ektodermalno-mezodermalnej i regulacyjnych procesów morfogenezy. Efektem tego jest m.in. ewolucja systemów klasyfikacyjnych uwzględniających, $\mathrm{w}$ coraz szerszym zakresie, genetyczną etiologię jako podstawowe kryterium różnicujące poszczególne jednostki chorobowe.

Jednakże pomimo tych osiągnięć, dla kilkudziesięciu chorób zaliczanych na podstawie objawów klinicznych do $\mathrm{DE}$, przyczyna choroby wciąż pozostaje nieznana, co nie dziwi biorąc pod uwagę stopień złożoności szlaków molekularnych związanych z etiopatogeneza molekularna DE. $\mathrm{Z}$ pewnością zatem $\mathrm{w}$ kolejnych latach będziemy mieli do czynienia $\mathrm{z}$ dalszymi odkryciami, $\mathrm{w}$ tym identyfikacją nowych genów, których mutacje są przyczynowo związane z DE.

\section{PIŚMIENNICTWO}

1. García-Martín P, Hernández-Martín A, Torrelo A (2013) Ectodermal dysplasias: a clinical and molecular review. Actas Dermosifiliogr 104: 451-470

2. Itin PH (2014) Etiology and pathogenesis of ectodermal dysplasias. Am J Med Genet A 164A: 2472-2477

3. Zadurska M, Jurek A, Milczarek A, Witanowska J, Pietrzak-Bilińska B, Mierzwińska-Nastalska E (2014) Dysplazja ektodermalna - przegląd piśmiennictwa. Prosthodontics 64: 252-259

4. Pinheiro M, Freire-Maia N (1994) Ectodermal dysplasias: a clinical classification and a causal review. Am J Med Genet 53: 153-162

5. Wright JT, Fete M, Schneider H, Zinser M, Koster MI, Clarke AJ, Hadj-Rabia S, Tadini G, Pagnan N, Visinoni AF, Bergendal B, Abbott B, Fete T, Stanford C, Butcher C, D'Souza RN, Sybert VP, Morasso MI (2019) Ectodermal dysplasias: Classification and organization by phenotype, genotype and molecular pathway. Am J Med Genet A 179: 442-447

6. Pagnan NAB, Visinoni ÁF (2014) Update on ectodermal dysplasias clinical classification. Am J Med Genet A 164A: 2415-2423

7. Martínez-Romero MC, Ballesta-Martínez MJ, López-González V, Sánchez-Soler MJ, Serrano-Antón AT, Barreda-Sánchez M, RodriguezPeña L, Martínez-Menchon MT, Frías-Iniesta J, Sánchez-Pedreño P, Carbonell-Meseguer P, Glover-López G, Guillén-Navarro E (2019) EDA, EDAR, EDARADD and WNT10A allelic variants in patients with ectodermal derivative impairment in the Spanish population. Orphanet J Rare Dis 14: 281
8. Salinas $\mathrm{CF}$, Irvine $\mathrm{AD}$, Itin $\mathrm{PH}$, Di Giovanna JJ, Schneider H, Clarke AJ, McGovern LS, Fete M (2014) Second International Conference on a classification of ectodermal dysplasias: development of a multiaxis model. Am J Med Genet A 164A: 2482-2489

9. Strachan LR, Ghadially R (2008) Tiers of clonal organization in the epidermis: the epidermal proliferation unit revisited. Stem Cell Rev 4:149-157

10. Mikkola ML, Thesleff I (2003) Ectodysplasin signaling in development. Cytokine Growth Factor Rev 14: 211-224

11. Cluzeau C, Hadj-Rabia S, Jambou M, Mansour S, Guigue P, Masmoudi S, Bal E, Chassaing N, Vincent M-C, Viot G, Clauss F, Manière M-C, Toupenay S, Le Merrer M, Lyonnet S, Cormier-Daire V, Amiel J, Faivre L, Prost Y de, Munnich A, Bonnefont J-P, Bodemer C, Smahi A (2011) Only four genes (EDA1, EDAR, EDARADD, and WNT10A) account for $90 \%$ of hypohidrotic/anhidrotic ectodermal dysplasia cases. Hum Mutat 32: 70-72

12. Kere J, Elomaa O (2002) Healing a natural knockout of epithelial organogenesis. Trends Mol Med 8: 197-200

13. Mikkola ML, Pispa J, Pekkanen M, Paulin L, Nieminen P, Kere J, Thesleff I (1999) Ectodysplasin, a protein required for epithelial morphogenesis, is a novel TNF homologue and promotes cell-matrix adhesion. Mech Dev 88: 133-146

14. Bayés M, Hartung AJ, Ezer S, Pispa J, Thesleff I, Srivastava AK, Kere J (1998) The anhidrotic ectodermal dysplasia gene (EDA) undergoes alternative splicing and encodes ectodysplasin-A with deletion mutations in collagenous repeats. Hum Mol Genet 7: 1661-1669

15. Blake JA, Richardson JE, Bult CJ, Kadin JA, Eppig JT (2002) The Mouse Genome Database (MGD): the model organism database for the laboratory mouse. Nucleic Acids Res 30: 113-115

16. Srivastava AK, Pispa J, Hartung AJ, Du Y, Ezer S, Jenks T, Shimada T, Pekkanen M, Mikkola ML, Ko MS, Thesleff I, Kere J, Schlessinger D (1997) The Tabby phenotype is caused by mutation in a mouse homologue of the EDA gene that reveals novel mouse and human exons and encodes a protein (ectodysplasin-A) with collagenous domains. Proc Natl Acad Sci U S A 94: 13069-13074

17. Yan M, Zhang Z, Brady JR, Schilbach S, Fairbrother WJ, Dixit VM (2002) Identification of a Novel Death Domain-Containing Adaptor Molecule for Ectodysplasin-A Receptor that Is Mutated in crinkled Mice. Curr Biol 12: 409-413

18. Headon DJ, Emmal SA, Ferguson BM, Tucker AS, Justice MJ, Sharpe PT, Zonana J, Overbeek PA (2001) Gene defect in ectodermal dysplasia implicates a death domain adapter in development. Nature 414: 913-916

19. Ferguson BM, Brockdorff N, Formstone E, Ngyuen T, Kronmiller JE, Zonana J (1997) Cloning of Tabby, the murine homolog of the human EDA gene: evidence for a membrane-associated protein with a short collagenous domain. Hum Mol Genet 6: 1589-1594

20. Elomaa O, Pulkkinen K, Hannelius U, Mikkola M, Saarialho-Kere U, Kere J (2001) Ectodysplasin is released by proteolytic shedding and binds to the EDAR protein. Hum Mol Genet 10: 953-962

21. Yan M, Wang LC, Hymowitz SG, Schilbach S, Lee J, Goddard A, Vos AM de, Gao WQ, Dixit VM (2000) Two-amino acid molecular switch in an epithelial morphogen that regulates binding to two distinct receptors. Science 290: 523-527

22. Sadier A, Viriot L, Pantalacci S, Laudet V (2014) The ectodysplasin pathway: from diseases to adaptations. Trends Genet 30: 24-31

23. Monreal AW, Ferguson BM, Headon DJ, Street SL, Overbeek PA, Zonana J (1999) Mutations in the human homologue of mouse dl cause autosomal recessive and dominant hypohidrotic ectodermal dysplasia. Nat Genet 22: 3 66-369

24. Wisniewski SA, Trzeciak WH (2012) A new mutation resulting in the truncation of the TRAF6-interacting domain of XEDAR: a possible novel cause of hypohidrotic ectodermal dysplasia. J Med Genet 49: 499-501

25. Kumar A, Eby MT, Sinha S, Jasmin A, Chaudhary PM (2001) The ectodermal dysplasia receptor activates the nuclear factor-kappaB, JNK, and cell death pathways and binds to ectodysplasin A. J Biol Chem 276: 2668-2677 
26. Morlon A, Munnich A, Smahi A (2005) TAB2, TRAF6 and TAK1 are involved in NF-kappaB activation induced by the TNF-receptor, Edar and its adaptator Edaradd. Hum Mol Genet 14: 3751-3757

27. Lefebvre S, Mikkola ML (2014) Ectodysplasin research - Where to next? Semin Immunol 26: 220-228

28. Trzeciak WH, Koczorowski R (2016) Molecular basis of hypohidrotic ectodermal dysplasia: an update. J Appl Genet 57: 51-61

29. Narayanan MJ, Rangasamy S, Narayanan V (2015) Incontinentia pigmenti (Bloch-Sulzberger syndrome). Handb Clin Neurol 132: 271-280

30. Shifera AS (2010) The zinc finger domain of IKKY (NEMO) protein in health and disease. J Cell Mol Med 14: 2404-2414

31. Naito A, Yoshida H, Nishioka E, Satoh M, Azuma S, Yamamoto T, Nishikawa S, Inoue J (2002) TRAF6-deficient mice display hypohidrotic ectodermal dysplasia. Proc Natl Acad Sci U S A 99:8766-8771

32. LefebvreS, Fliniaux I, Schneider P, Mikkola ML (2012) Identification of ectodysplasin target genes reveals the involvement of chemokines in hair development. J Invest Dermatol 132: 1094-1102

33. Jaskoll T, Zhou Y-M, Trump G, Melnick M (2003) Ectodysplasin receptor-mediated signaling is essential for embryonic submandibular salivary gland development. Anat Rec A Discov Mol Cell Evol Biol 271: 322-331

34. Mikkola ML (2011) The Edar subfamily in hair and exocrine gland development. Adv Exp Med Biol 691: 23-33

35. Häärä O, Fujimori S, Schmidt-Ullrich R, Hartmann C, Thesleff I, Mikkola ML (2011) Ectodysplasin and Wnt pathways are required for salivary gland branching morphogenesis. Development 138: 2681-269

36. Laurikkala J, Pispa J, Jung H-S, Nieminen P, Mikkola M, Wang X, Saarialho-Kere U, Galceran J, Grosschedl R, Thesleff I (2002) Regulation of hair follicle development by the TNF signal ectodysplasin and its receptor Edar. Development 129: 2541-2553

37. Häärä O, Harjunmaa E, Lindfors PH, Huh S-H, Fliniaux I, Åberg T, Jernvall J, Ornitz DM, Mikkola ML, Thesleff I (2012) Ectodysplasin regulates activator-inhibitor balance in murine tooth development through Fgf20 signaling. Development 139:3189-3199

38. Mikkola ML (2008) TNF superfamily in skin appendage development. Cytokine Growth Factor Rev 19:219-230

39. Yang A, Kaghad M, Wang Y, Gillett E, Fleming MD, Dötsch V, Andrews NC, Caput D, McKeon F (1998) p63, a p53 Homolog at 3q27-29, Encodes Multiple Products with Transactivating, Death-Inducing, and Dominant-Negative Activities. Mol Cell 2: 305-316

40. King KE, Weinberg WC (2007) p63: defining roles in morphogenesis, homeostasis, and neoplasia of the epidermis. Mol Carcinog 46: 716-724

41. Irwin MS, Kaelin WG (2001) p53 family update: p73 and p63 develop their own identities. Cell Growth Differ 12: 337-349

42. Osada M, Park HL, Nagakawa Y, Yamashita K, Fomenkov A, Kim MS, Wu G, Nomoto S, Trink B, Sidransky D (2005) Differential recognition of response elements determines target gene specificity for p53 and p63. Mol Cell Biol 25: 6077-6089

43. Candi E, Rufini A, Terrinoni A, Dinsdale D, Ranalli M, Paradisi A Laurenzi V de, Spagnoli LG, Catani MV, Ramadan S, Knight RA, Melino G (2006) Differential roles of p63 isoforms in epidermal development: selective genetic complementation in p63 null mice. Cell Death Differ 13: 1037-1047

44. Mikkola ML (2007) p63 in skin appendage development. Cell Cycle 6: $285-290$

45. Barton CE, Johnson KN, Mays DM, Boehnke K, Shyr Y, Boukamp P, Pietenpol JA (2010) Novel p63 target genes involved in paracrine signaling and keratinocyte differentiation. Cell Death Dis 1: e74
46. Cambiaghi S, Restano L, Pääkkönen K, Caputo R, Kere J (2000) Clinical findings in mosaic carriers of hypohidrotic ectodermal dysplasia. Arch Dermatol 136: 217-224

47. Lu PD, Schaffer JV (2008) Hypohidrotic ectodermal dysplasia. Dermatol Online J 14: 22

48. Schneider H, Hammersen J, Preisler-Adams S, Huttner K, Rascher W, Bohring A (2011) Sweating ability and genotype in individuals with X-linked hypohidrotic ectodermal dysplasia. J Med Genet 48: 426-432

49. Bal E, Baala L, Cluzeau C, El Kerch F, Ouldim K, Hadj-Rabia S, Bodemer C, Munnich A, Courtois G, Sefiani A, Smahi A (2007) Autosomal dominant anhidrotic ectodermal dysplasias at the EDARADD locus. Hum Mutat 28: 703-709

50. Wohlfart S, Hammersen J, Schneider H (2016) Mutational spectrum in 101 patients with hypohidrotic ectodermal dysplasia and breakpoint mapping in independent cases of rare genomic rearrangements. J Hum Genet 61: 891-897

51. Rafatjoo R, Taghdisi Kashani A (2016) Incontinentia Pigmenti; a Rare Multisystem Disorder: Case Report of a 10-Year-Old Girl. J Dent (Shiraz) 17: 233-237

52. Roelfsema NM, Cobben JM (1996) The EEC syndrome: a literature study. Clin Dysmorphol 5: 115-127

53. Brunner HG, Hamel BCJ, van Bokhoven H (2002) The p63 gene in EEC and other syndromes. J Med Genet 39: 377-381

54. Julapalli MR, Scher RK, Sybert VP, Siegfried EC, Bree AF (2009) Dermatologic findings of ankyloblepharon-ectodermal defects-cleft lip/ palate (AEC) syndrome. Am J Med Genet A 149A: 1900-1906

55. Dishop MK, Bree AF, Hicks MJ (2009) Pathologic changes of skin and hair in ankyloblepharon-ectodermal defects-cleft lip/palate (AEC) syndrome. Am J Med Genet A 149A: 1935-1941

56. Avitan-Hersh E, Indelman M, Bergman R, Sprecher E (2010) ADULT syndrome caused by a mutation previously associated with EEC syndrome. Pediatr Dermatol 27: 643-645

57. van Bokhoven H, Hamel BC, Bamshad M, Sangiorgi E, Gurrieri F, Duijf PH, Vanmolkot KR, van Beusekom E, van Beersum SE, Celli J, Merkx GF, Tenconi R, Fryns JP, Verloes A, Newbury-Ecob RA, Raas-Rotschild A, Majewski F, Beemer FA, Janecke A, Chitayat D, Crisponi G, Kayserili H, Yates JR, Neri G, Brunner HG (2001) p63 Gene mutations in eec syndrome, limb-mammary syndrome, and isolated split hand-split foot malformation suggest a genotype-phenotype correlation. Am J Hum Genet 69: 481-492

58. Kannu P, Savarirayan R, Ozoemena L, White SM, McGrath JA (2006) Rapp-Hodgkin ectodermal dysplasia syndrome: the clinical and molecular overlap with Hay-Wells syndrome. Am J Med Genet A 140: 887-891

59. Freire-Maia N (1971) Ectodermal dysplasias. Hum Hered 21: 309-312

60. Freire-Maia N (1977) Ectodermal dysplasias revisited. Acta Genet Med Gemellol 26: 121-131

61. Lamartine J (2003) Towards a new classification of ectodermal dysplasias. Clin Exp Dermatol 28: 351-355

62. Priolo M, Laganà C (2001) Ectodermal dysplasias: a new clinical genetic classification. J Med Genet 38: 579-585

63. Priolo M (2009) Ectodermal dysplasias: an overview and update of clinical and molecular-functional mechanisms. Am J Med Genet A 149A: 2003-2013

64. Visinoni AF, Lisboa-Costa T, Pagnan NAB, Chautard-Freire-Maia EA (2009) Ectodermal dysplasias: clinical and molecular review. Am J Med Genet A 149A: 1980-2002 


\title{
Ectodermal dysplasis - molecular mechanisms responsible for the occurrence of the most frequent syndroms
}

\author{
Alicja Monika Grabarczyk ${ }^{\varpi}$, Katarzyna Wertheim-Tysarowska, Jerzy Bal \\ Institute of Mother and Child, Warsaw \\ $\unrhd^{\circledR}$ Corresponding author: alicja.grabarczyk@imid.med.pl
}

Key words: ectodermal dysplasias, morphogenesis, signal pathways, ectodysplasin, classification

\begin{abstract}
Ectodermal dysplasias are a wide group of genetic disorders characterised by clinical symptoms in ectodermal derivatives (most frequently teeth, hair, nails and sweat glands). There is a number of genes, which, if mutated, can cause the specified phenotype. The molecular basis of many ectodermal dysplasias have been investigated. The phenotype often results from the imparied communication in molecular pathways important in embryonic morphogenesis or disturbed function of protein complexes involved in homeostasis, adhesion and stability of the cells in the tissue. Different classification systems have been proposed to group ectodermal dysplasias according to clinical symptoms or molecular basis. Molecular technologies has let recently to expand diagnostic abilities for ectodermal dysplasias patients. Certainly in the nearest years new genes and mutations will be discovered as a cause of ectodermal dysplasias.
\end{abstract}

\section{DYSPLAZJE EKTODERMALNE - MECHANIZMY MOLEKULARNE ODPOWIEDZIALNE ZA WYSTĘPOWANIE NAJCZĘSTSZYCH ZESPOŁÓW CHOROBOWYCH}

\section{Dysplazje ektodermalne}

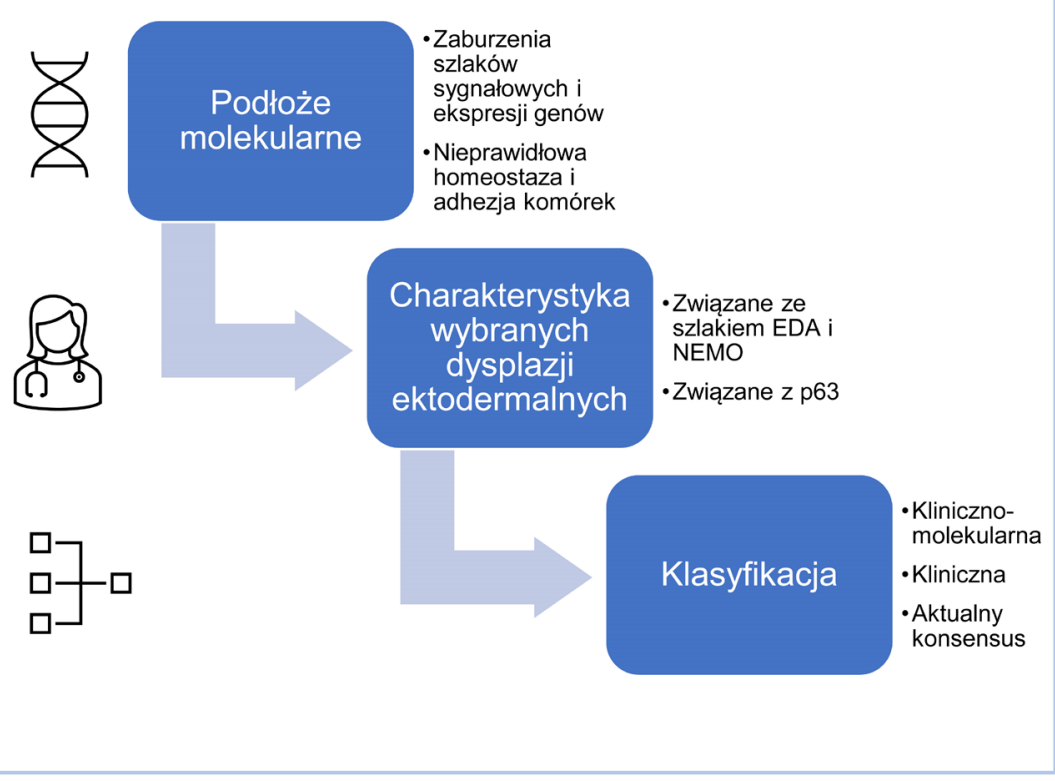

\section{Co wiemy o DE:}

Znanych ponad 180

zespołów

Zaburzenia rozwoju

i/lub homeostazy

dwóch lub więcej

pochodnych

ektodermalnych

Objawy najczęściej

dotyczą: włosów,

zębów, paznokci,

gruczołów

Najczęściej występuje:

XLHED 1:150000-

100000 osób

Dziedziczenie: $A R, A D$,

$X L R, X L D$ 